\title{
Environmental Noise Pollution and its Impacts on the Hearing Ability of Men and Women in Ilorin, Kwara State, Nigeria
}

\author{
Afolabi M. Tunde* and Salamat Abdulquadri \\ Department of Geography \& Environmental Management, University of Ilorin, Nigeria. \\ *Corresponding author, e-mail: afolabi@unilorin.edu.ng \\ Received 31 May 2021, Revised 14 Oct 2021, Accepted 23 Oct 2021, Published Dec 2021 \\ DOI: https://dx.doi.org/10.4314/tjs.v47i5.3
}

\begin{abstract}
Noise is an environmental disturbance that has harmful effects on the physiological and psychological lives of human beings and animals. This work examined the perceived health implications associated with noise pollution on both genders in Ilorin, Nigeria. It specifically identified the major sources of noise pollution, assessed noise pollution levels in the selected areas and determined the differences in the impacts of noise pollution on the health of both genders in Ilorin. A total of 384 respondents were sampled. Sound Level Meter (SLM) was used to ascertain the levels of noise in the study areas. Descriptive statistics and ANOVA were used to analyze the gathered data. Findings revealed that $73.2 \%$ of the respondents believed that traffic constitutes the highest source of noise pollution while others include music studios $(63.3 \%)$, hotels/night clubs $(52.1 \%)$ and power generating sets $(50 \%)$. Noise levels were higher than the acceptable recommended noise level of 65 decibels for commercial and 55 decibels for commercial/residential locations by NESREA. Findings further revealed that males are more susceptible to the effects of noise pollution than females. Hence, possible mitigation measures such as noise pollution regulatory policy enactment and design of noise absorbing structures are strongly recommended.
\end{abstract}

Keywords: Diseases, Gender, Health Risks, Impacts, Noise.

\section{Introduction}

Noise can be defined as any unpleasant or disturbing sound that causes unwanted effects. Such unwanted effects are usually manifested through direct pathways or indirectly, involving cognitive perceptions (Babisch 2002). Noise often regarded as a "silent killer" has been detected as an important environmental health issue that many people are not conscious of (Clark and Stanfeld 2007). According to Ijaiya (2014) the word noise is derived from Latin term "nausa" defined in law as "excessive, offensive, persistent or startling sound". However, Eriksson et al. (2012), regarded community noise as a common environmental nuisance and a noticeable menace to human health. Similarly, Schomer (2001) defined environmental noise as the noise emitted from all sources except in the industrial workplace hence, noise pollution is ranked as the third most hazardous form of pollution after air and water pollution (WHO 2005).

Major causes of noise pollution as pointed out by Nwabuogo and Stephen (2017) include: growing global population, increase in technological advancement and human activities. These have resulted in health risks to human beings. Health implication is regarded as an uncertain outcome of an exposure to activity that can affect human value (IRGC 2005). This may be direct (auditory) or indirect (non-auditory) adverse effects. Eriksson et al. (2012) further listed some of the adverse effects of noise pollution on human to include sleep disturbance, 
hearing impairment, cognitive effects, anxiety, psychological stress, depression, tension, irritability, interference with speech, reduced efficiency and annoyance amongst others. Most of these adverse effects cause risks to human health. About $10 \%$ of the global population is currently exposed to noise levels that could lead to hearing impairments (Basner et al. 2014). Many studies conducted on noise pollution in different countries of the world ( $\mathrm{Li}$ et al. 2002, Zannin et al. 2002, Singh and Davar 2004, Alberola et al. 2005, Lebiedowska 2005, Pucher et al. 2005, Tansatcha et al. 2005) have revealed the scales of discomfort that noise causes in people's lives.

Noise is typical of urban areas than the rural areas. The number of people exposed to noise pollution as a result of population and urbanization is increasing on daily basis. For instance, in Europe (EEA 2009, WHO 2009), $67 \%$ of the population living in communities with more than 250,000 inhabitants are exposed to road traffic noise levels exceeding the WHO guideline value of $55 \mathrm{dBL}_{\mathrm{den}}$. Also, Negahdari et al. (2018) studied the risk of noise pollution that resulted from central traffic in Shiraz by analyzing its indicators and related components, they discovered that the sound pressure levels exceeded the environmental standards of Iran and the values of the pressure levels were higher than the standard of comfort at night and day. Eriksson et al. (2017) carried out a similar study in Sweden and reported that both road traffic and railway noise contributed to the burden of disease including nearly 1,000 cases of myocardial infections yearly. Likewise, Pyko (2018) investigated long-term exposure to transportation noise in relation to metabolic and cardiovascular outcomes in Stockholm County, Sweden. Findings from that study indicated adverse effects of longterm transportation noise exposure on some metabolic and cardiovascular outcomes.

When compared with some countries of the world, Nigerians are living in more noisepolluted environments. In Nigeria, the Federal Environmental Protection Agency (FEPA) provided daily noise exposure limits for workers in industry as $90 \mathrm{~dB}$ (A) for $8 \mathrm{~h}$ exposure. Meanwhile, in Ghana it is $48 \mathrm{~dB}$ (A) for night-time and $55 \mathrm{~dB}$ (A) in the day (Essando et al. 2011), Egypt standard at daytime remains $71 \mathrm{~dB}(\mathrm{~A})$, while the night $66 \mathrm{~dB}$ (A) (Kamal et al. 2010), Great Britain average standard is $80 \mathrm{~dB}$ (A) (HSE 2005) and the USA $85 \mathrm{~dB}$ (A) (NIOSH 2010). The sources of noise pollution in Nigeria include traffic noise, highly amplified music from record shops and hotels, construction companies, industrial activities, private electricity-generating plants, religious institutions, loudspeakers, sporting events, political rallies, bells rung incessantly by peddlers, hawkers, road advertisements and grinding machines among others. Noise pollution has been linked to a number of health-related ailments such as depression, anger, weak concentration and hearing defects (Nwabuogo and Stephen 2017). Ijaiya (2014) examined noise pollution in Nigeria and the legal regime relating to the problem. He concluded that proper approaches to address the issue of noise and protection of human and environmental health in Nigeria should be evolved based on the adverse effects it has on both human health and the environment.

Godson et al. (2009) studied noise and its associated health impacts at some selected secondary schools in Ibadan, Nigeria and reported that over $60 \%$ of sampled respondents supported that vehicular traffic was their major source of noise leading to lack of concentration. In the same vein, Awosusi and Akindutire (2014) examined the level of awareness of health problems associated with noise pollution and the relationship between locations and the perceived health effects among inhabitants of Ado Ekiti, Nigeria. They discovered that residents were aware of the health effects of noise pollution and a significant relationship was established between location and the perceived health effects of noise pollution. Similarly, Oloruntoba et al. (2012) assessed the sources, noise levels, and possible impacts in selected residential neighbourhoods of Ibadan metropolis and discovered that the periods at which noise level reaches its peak vary with population density. 
Oyedepo (2012) also analyzed environmental noise pollution in Ilorin metropolis and observed that sound level varies with location and period of the day with an average daily noise of $46 \mathrm{~dB}$ (A) to $86 \mathrm{~dB}$ (A). According to him, noise pollution generally in this town is due to traffic characteristics, especially traffic volume, vehicle horns, vehicle-mounted loudspeakers, record players and hawking. There is high LAeq, L90 and L10 at road junctions $(77 \mathrm{~dB}$ A, $66 \mathrm{~dB} \mathrm{~A}, 77 \mathrm{~dB}$ A), passengers loading parks $(76 \mathrm{~dB} A, 66 \mathrm{~dB} A, 77 \mathrm{~dB} A)$ and commercial centres $(73 \mathrm{~dB}$ A, $64 \mathrm{~dB}$ A, 74 $\mathrm{dB} A$ ). In spite of all these studies, there existed a gap that needed to be filled. What actually prompted this study has to do with the way people contribute to noise pollution in the environment through honking by automobiles, playing loud music, religious activities with the use of loudspeakers, use of generating sets among others. The issue is do people even know that noise affects human health? Is there any difference between the impacts of noise pollution on men and women? Hence, this study examined the perceived health risks associated with noise pollution by men and women in Ilorin, Kwara State, Nigeria for possible mitigation strategies. The work specifically identified the major sources of noise pollution, assessed the environmental noise pollution levels in the selected areas and determined if differences existed in the impacts of noise pollution on the health of men and women in Ilorin as an urban centre and capital of Kwara State, Nigeria.

\section{Materials and Methods}

Ilorin lies between latitudes $8^{\circ} 30^{\prime} \mathrm{N} \&$ $8^{\circ} 50^{\prime} \mathrm{N}$ and longitude $4^{\circ} 20^{\prime} \mathrm{E} \& 4^{\circ} 36^{\prime} \mathrm{E}$ (Figure 1) with an area of about $100 \mathrm{~km}^{2}$ (Kwara State of Nigeria Diary 2009). Ilorin, the Kwara State Capital comprises three Local Government Areas, namely: Ilorin West, Ilorin East and Ilorin South. The city has been selected because of the increased heterogeneous population over the years and urbanization, which made it a good ground for the study of this nature. Ilorin is relatively a large urban centre with an increasing population growth rate. The 2006 population figures showed that the city had a population of 766,000 (NPC 2006). The city has experienced great urbanization and expansion continuously in all directions in the last two decades. Ilorin has experienced many significant changes in terms of urbanization, industrialization, expansion of road-network and infrastructures. Within the metropolis, the major occupations include trading, civil services of varying cadres and persuasions and a host of informal sector services. Like many traditional cities in Nigeria, Ilorin retains the characteristics of traditional town alongside a modern urban centre because of the presence of both traditional and modern buildings.

According to Olaniran (2002), Ilorin experienced tropical wet and dry climate with mean annual rainfall of 1,200 mm. Ilorin falls within derived savannah vegetation with the existence of dry lowland rain forest vegetal cover. The wet season falls between March and October while the dry season falls between the months of November and February. The city has a varying temperature between $25{ }^{\circ} \mathrm{C}$ to $30{ }^{\circ} \mathrm{C}$ in March which marks the hottest month (Olanrewaju 2009). The vegetation is characterized by scattered tall trees such as baobab, locust beans, shear butter, acacia, etc. The city in its geological settings consists of Pre-Cambrian basement complex with an elevation between $273 \mathrm{~m}$ to $333 \mathrm{~m}$ above sea level (Ifabiyi et al. 2016). There is an isolated hill (Sobi hills) of about $394 \mathrm{~m}$ above sea level towards the North of the western part and $200 \mathrm{~m}$ to $346 \mathrm{~m}$ in the East (Ajibade 2002). The city is covered mainly by ferruginous soil on crystalline acidic rocks. According to Tunde (2017) the pattern of the drainage system of Ilorin is dendritic due to its characteristics. The most important river is Asa River which flows in northern direction. Asa River occupies a fairly wide valley and goes a long way to divide Ilorin into two parts namely the eastern and the western parts. The eastern part covers those areas where the GRA is located, while the core indigenes areas of Ilorin fall under the western part. The other Rivers that drain into Asa River are River Agba, River 
Alalubosa, River Okun, River Osere and River Aluko.

For this study, twenty-seven (27) different locations involving major road junctions and commercial centres surrounded by noisy activities were selected. These locations are representations for all wards in the study area based on INEC Directory of Ilorin Metropolis (INEC 2015). Sound Level Meter (SLM) was used to ascertain the level of environmental noise levels in the 27 locations. These were recorded for five (5) days. Measurement was done at intervals of 30 seconds for 10 minutes and the average of the interval measured was used to represent the specific time of the day (Baloye and Palamuleni 2015). This procedure was done for morning (7.00-11.00 am), afternoon (12.00-4.00 pm) and evening (5.00-9.00pm). Global Positioning System (GPS) was used to collect coordinates of the selected areas. Audiometer was used to examine the risks of direct effects of noise on residents. The 2019 INEC registered voters of $452,930,099$ (INEC 2019) was used which was more recent and updated in relation to accurate political ward distribution of Ilorin metropolis. Krejcie and Morgan (1970) sample size table was employed to determine the sample size for the study which was 384 respondents. Systematic random sampling of $1^{\text {st }}, 3^{\text {rd }}, 5^{\text {th }}, 7^{\text {th }}$, and $9^{\text {th }}$ for every individual was observed to be surrounded by noise. This was done until the number of samples needed was covered for each sample locations. The National Environmental Standards and Regulations Enforcement Agency (NESREA 2009) community noise exposure guidelines for the general environments and the hearing schemes in Nigeria were used for this work (Table 1).

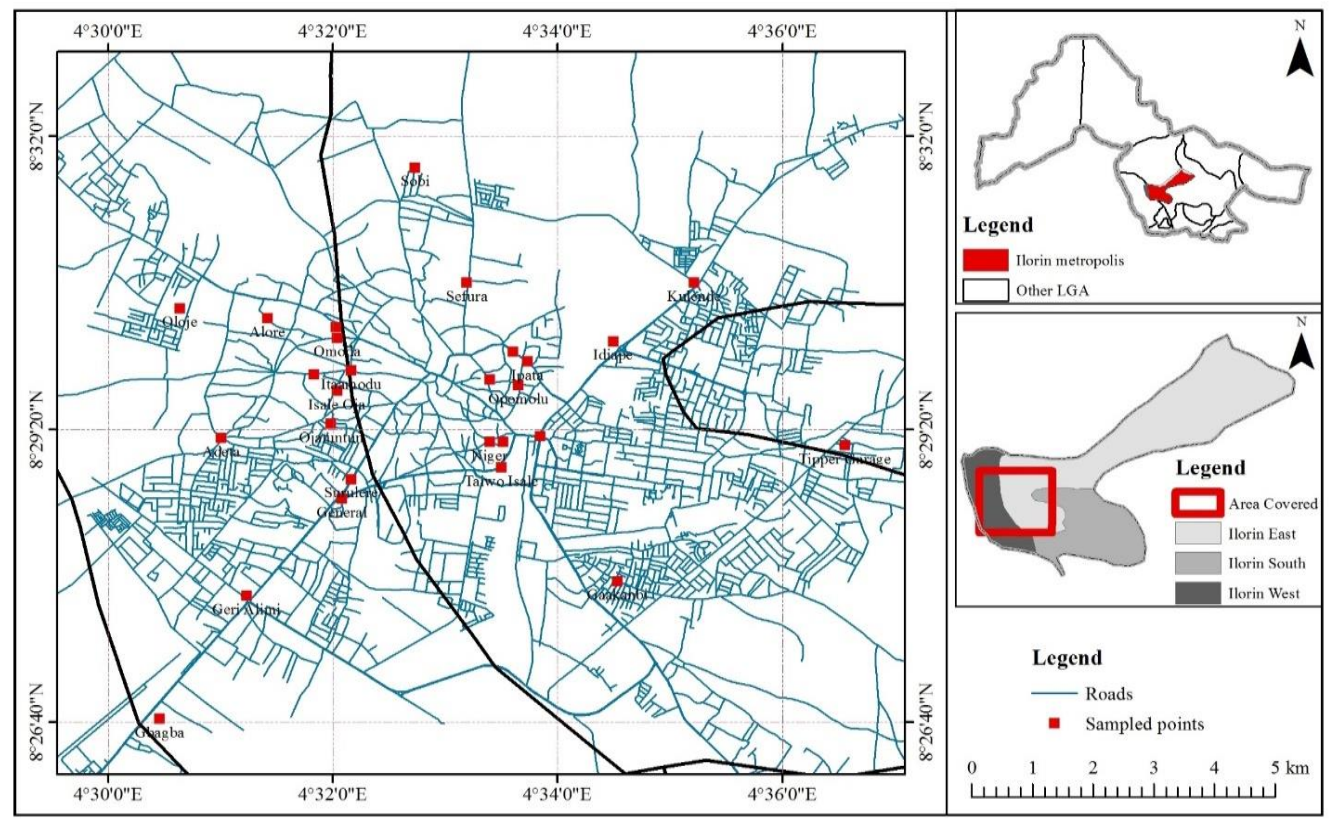

Figure 1: Ilorin showing sampled locations. Source: Ministry of Lands and Housing (2018). 
Table 1: Maximum permissible noise levels for general environment

\begin{tabular}{|l|l|c|}
\hline & Facility & $\begin{array}{l}\text { Maximum permissible noise } \\
\text { limit dB (A) (Leq): During the } \\
\text { day }\end{array}$ \\
\hline A & $\begin{array}{l}\text { Any building used as hospital, convalescence } \\
\text { home, home for the aged, sanatorium and institutes } \\
\text { of higher learning, conference rooms, public } \\
\text { library, environmental or recreational sites. }\end{array}$ & 45 \\
\hline B & Residential buildings & 50 \\
\hline C & $\begin{array}{l}\text { Mixed residential (with some commercial } \\
\text { entertainments) }\end{array}$ & 55 \\
\hline D & $\begin{array}{l}\text { Residential + industry or small-scale production }+ \\
\text { commerce }\end{array}$ & 60 \\
\hline E & Commercial & 70 \\
\hline F & Industrial (outside perimeter fence) & 65 \\
\hline
\end{tabular}

Source: National Environmental Standards and Regulations Enforcement Agency Act (2009). Time-frame: 6:00 am-10:00 pm, with consideration of human activities.

\section{Results and Discussion}

\section{Gender and age distribution}

From the study, out of 384 respondents that were sampled, $54.4 \%$ were males as against $45.6 \%$ females (Figure 2). This indicates that males are more involved in noise-related activities than the females. This is similar to Shehu et al. (2019) findings that majority $(61.1 \%)$ of respondents under study were males.
Figure 3 shows the age distribution of the respondents, 20-29 years of age were 56 (14.6\%), 30-39 years were $176(45.8 \%), 40$ 49 years of age were $116(30.2 \%)$ and 50-59 years of age were $36(9.4 \%)$. This indicates that majority $(90.6 \%)$ of the sampled respondents were between the age of 20 and 49 years (economic active age). This is in support of Aremu et al. (2015) that about $80 \%$ of the respondents under study fall within the active age groups of 14-57 years.

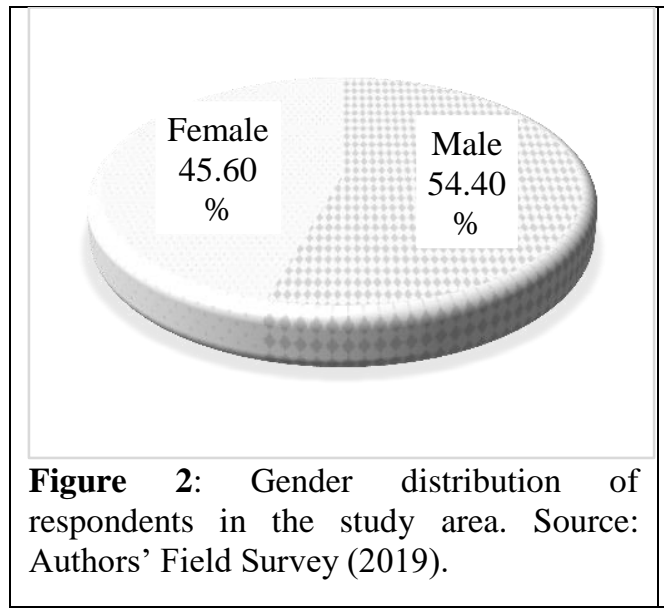

Sources of noise pollution and perception of exposure to noise

The study revealed that there were various sources of noise pollution in the study area and these include road (vehicles, bikes,

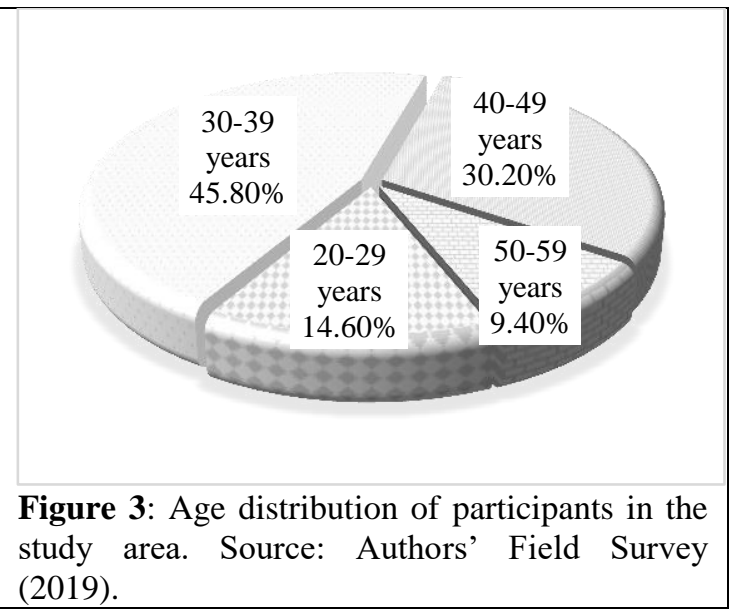

tricycle) and rail junctions (train), music studio, night clubs, hotels, market, power generating plants, religious institutions such as mosques and churches, construction, industrial activities/saw milling, private 
sporting events, political rallies, incessant ringing of bells by peddlers, hawkers, road advertisements, and grinding machines among others. Table 2 shows the major sources of noise pollution in the study areas.

In aggregate, $73.2 \%$ of the respondents believed that traffic constitutes the highest source of noise pollution in the environment. This is in line with the study carried out by Farooqi et al. (2020) that traffic noise is a major source of noise. Also, $63.3 \%$ of them agreed that musical shops generated noise, while $52.1 \%$ confirmed that club houses and hotels contribute highly to noise pollution and $50 \%$ said power generating plant is also significant. On the other hand, the least noise generating factor is sporting events/viewing centres because they are occasional events.

Furthermore, $78.6 \%$ are being exposed to daily noise of 8 hours and above while $0.5 \%$ was exposed to noise between 2 to 4 hours, $85.7 \%$ of the respondents had been staying in their selected noise polluted locations for more than 12 months while very few $(0.5 \%)$ lived in such locations below one month. The implication of this is that, ignorance has contributed to the belief that noise has no impact on the health of the sampled respondents in spite of their exposure to it.

Table 2: Sources of noise pollution and perception of exposure to noise

\begin{tabular}{|c|c|c|c|c|c|}
\hline Sources of noise & $\begin{array}{l}\text { Extremely } \\
\text { severe N } \\
(\%)\end{array}$ & $\begin{array}{l}\text { Severe } \\
\mathrm{N}(\%)\end{array}$ & $\begin{array}{l}\text { Undecided } \\
\mathrm{N}(\%)\end{array}$ & $\begin{array}{l}\text { Not } \\
\text { severe } \\
\text { N (\%) }\end{array}$ & $\begin{array}{l}\text { Extremely } \\
\text { not severe } \\
\mathrm{N}(\%)\end{array}$ \\
\hline Traffic & $281(73.2)$ & $71(18.5)$ & $0(0)$ & $28(7.3)$ & $4(1.0)$ \\
\hline Construction/Industrial/sawmills & $180(46.9)$ & $95(24.7)$ & $40(10.4)$ & $44(11.5)$ & $25(6.5)$ \\
\hline Musical shops & $243(63.3)$ & $112(29.2)$ & $20(5.2)$ & $7(1.8)$ & $2(0.5)$ \\
\hline Bar/Club houses/hotels & $200(52.1)$ & $102(26.6)$ & $50(13.0)$ & $22(5.7)$ & $10(2.6)$ \\
\hline Religious activities & $140(36.5)$ & $125(32.6)$ & $23(5.9)$ & $56(14.6)$ & $40(10.4)$ \\
\hline Power generating plants & $192(50)$ & $179(46.6)$ & $10(2.6)$ & $2(0.5)$ & $1(0.3)$ \\
\hline Market/road advertisements, & $191(49.7)$ & $159(41.4)$ & $10(2.6)$ & $14(3.7)$ & $10(2.6)$ \\
\hline $\begin{array}{l}\text { Sporting event/football viewing } \\
\text { centers }\end{array}$ & $102(26.6)$ & $138(35.9)$ & $50(13.0)$ & $70(18.2)$ & $24(6.3)$ \\
\hline $\begin{array}{l}\text { Neighborhood noise (Grinding } \\
\text { machines, music, etc) }\end{array}$ & $150(39.1)$ & $134(10.7)$ & $53(0.8)$ & $28(17.7)$ & $19(4.9)$ \\
\hline Length of exposure & 2-4 Hours & 4-6 Hours & 6-8 Hours & $\begin{array}{l}8 \text { Hours } \\
\text { and above }\end{array}$ & \\
\hline Daily exposure per hours & $2(0.5)$ & $15(3.9)$ & $61(15.9)$ & $302(78.6)$ & \\
\hline \multirow[t]{2}{*}{ Duration of stay at the location } & $\begin{array}{l}\text { Less than } 1 \\
\text { month }\end{array}$ & $\begin{array}{l}12-4 \\
\text { months }\end{array}$ & 4-8 months & $\begin{array}{l}8-12 \\
\text { months }\end{array}$ & $\begin{array}{l}12 \text { months } \\
\& \text { above }\end{array}$ \\
\hline & $2(0.5)$ & $7(1.8)$ & $10(2.6)$ & $36(9.4)$ & $329(85.7)$ \\
\hline
\end{tabular}

Sources: Authors' Field Survey (2019).

\section{Environmental noise pollution levels}

Table 3 shows the summary of the levels of noise pollution recorded for each of the sampled 27 locations in the study areas for morning, afternoon and evening. The mean, average and maximum noise levels for the morning were: $73.07 \mathrm{~dB}(\mathrm{~A}), 64.80 \mathrm{~dB}(\mathrm{~A})$ and $87.44 \mathrm{~dB} \quad(\mathrm{~A})$ and the evening observations measurements were: $76.93 \mathrm{~dB}$ (A), $64.70 \mathrm{~dB}$ (A) and $89.63 \mathrm{~dB}$ (A), respectively. 
Table 3: Extent of environmental noise pollution in selected locations of Ilorin Metropolis

\begin{tabular}{|c|c|c|c|c|c|c|c|c|c|c|}
\hline \multirow[t]{2}{*}{ Locations } & \multicolumn{3}{|c|}{ Morning $\left(\mathrm{L}_{\mathrm{Aeq}}\right)$} & \multicolumn{3}{|c|}{ Afternoon $\left(\mathrm{L}_{\mathrm{Aeq}}\right)$} & \multicolumn{3}{|c|}{ Evening $\left(\mathrm{L}_{\mathrm{Aeq}}\right)$} & \multirow{2}{*}{$\begin{array}{l}\mathrm{D} \\
\left(\mathrm{L}_{\mathrm{Aeq}}\right) \\
\mathrm{Av} . \mathrm{Tl}\end{array}$} \\
\hline & Min & Max & Avg & Min & Max & Avg & Min & Max & Avg & \\
\hline Adeta & 63.0 & 81.0 & 73.7 & 61.0 & 80.0 & 73.1 & 63.0 & 80.3 & 74.4 & 78.5 \\
\hline Omoda & 64.0 & 79.0 & 71.1 & 62.0 & 84.0 & 72.6 & 67.0 & 84.0 & 73.7 & 77.3 \\
\hline Surulere & 61.0 & 87.0 & 72.5 & 64.0 & 78.0 & 73.7 & 66.0 & 91.0 & 72.6 & 78.8 \\
\hline General hospital & 59.0 & 80.0 & 70.4 & 58.0 & 81.0 & 74.4 & 66.0 & 94.0 & 74.9 & 78.4 \\
\hline Oja-tuntun & 62.4 & 78.9 & 69.0 & 64.0 & 85.0 & 76.4 & 65.0 & 86.0 & 73.3 & 78.6 \\
\hline Isale-Oja & 64.3 & 79.2 & 71.9 & 62.4 & 84.2 & 75.2 & 66.0 & 85.0 & 77.7 & 80.3 \\
\hline Oloje & 65.2 & 80.2 & 72.1 & 64.0 & 80.9 & 71.6 & 63.8 & 87.0 & 72.3 & 76.7 \\
\hline Ogidi/Alore & 63.2 & 80.5 & 70.3 & 67.0 & 79.2 & 73.1 & 64.8 & 83.5 & 73.3 & 77.2 \\
\hline Oju-ekun & 62.2 & 79.8 & 72.0 & 64.7 & 82.5 & 72.3 & 65.0 & 84.9 & 70.8 & 76.5 \\
\hline Geri Alimi & 62.6 & 82.1 & 73.2 & 63.4 & 84.4 & 73.9 & 64.2 & 87.8 & 76.4 & 79.4 \\
\hline Ita-Amon & 63.0 & 80.9 & 70.9 & 64.8 & 83.4 & 75.0 & 63.1 & 90.0 & 74.2 & 78.4 \\
\hline Gbagba & 60.9 & 81.3 & 68.5 & 65.6 & 82.0 & 72.7 & 64.9 & 80.9 & 71.6 & 76.0 \\
\hline Gaa-akanbi & 61.2 & 79.4 & 70.5 & 63.7 & 84.0 & 73.9 & 63.7 & 83.5 & 73.8 & 77.7 \\
\hline Tipper Garage & 60.9 & 86.3 & 72.5 & 65.6 & 82.0 & 74.7 & 66.4 & 94.1 & 72.7 & 78.1 \\
\hline Kulende & 61.7 & 84.8 & 73.3 & 62.5 & 79.0 & 76.0 & 62.2 & 86.6 & 74.3 & 78.9 \\
\hline Gbagede & 63.1 & 81.2 & 69.8 & 63.3 & 82.6 & 75.8 & 63.8 & 83.0 & 73.0 & 78.3 \\
\hline Opo-malu & 62.5 & 82.4 & 70.6 & 65.0 & 85.0 & 74.0 & 64.2 & 85.3 & 74.3 & 78.0 \\
\hline Niger & 63.0 & 79.3 & 70.1 & 63.6 & 80.2 & 76.4 & 65.7 & 81.3 & 72.7 & 78.6 \\
\hline Taiwo-Isale & 65.3 & 78.7 & 72.3 & 63.1 & 88.1 & 75.1 & 65.4 & 80.0 & 75.0 & 79.1 \\
\hline Ita-amodu & 63.6 & 83.1 & 71.5 & 63.5 & 79.8 & 72.2 & 65.0 & 83.5 & 73.0 & 77.0 \\
\hline Ita-akure & 61.3 & 82.8 & 70.9 & 62.8 & 78.6 & 72.8 & 63.0 & 86.3 & 74.1 & 77.6 \\
\hline Gambari & 61.5 & 80.9 & 71.4 & 65.2 & 86.0 & 74.0 & 64.3 & 83.8 & 73.2 & 79.0 \\
\hline Sobi & 66.0 & 81.2 & 71.8 & 65.3 & 84.9 & 73.9 & 63.4 & 87.6 & 74.0 & 78.1 \\
\hline Sefura & 60.9 & 79.7 & 68.2 & 66.8 & 85.4 & 72.1 & 64.0 & 90.2 & 71.2 & 75.6 \\
\hline Idiape & 63.7 & 84.2 & 69.4 & 65.8 & 79.6 & 76.0 & 63.3 & 87.3 & 74.9 & 79.4 \\
\hline Post-office & 66.4 & 83.2 & 71.5 & 64.7 & 88.2 & 77.5 & 65.2 & 84.1 & 77.6 & 81.1 \\
\hline Ipata & 63.6 & 84.5 & 74.0 & 64.5 & 84.1 & 75.7 & 68.4 & 84.7 & 75.5 & 79.9 \\
\hline Average & 65.9 & 117.4 & 83.7 & 66.8 & 123.9 & 93.3 & 67.0 & 131.1 & 93.9 & \\
\hline
\end{tabular}

*Sampling time range: 30 Secs for 10 mins in the morning, afternoon and evening for 5 days

Source: Authors' Field Survey (2019).

The summary of the results for each is presented in Table 3. The total average noise level of the results presented was arrived at by using the LAeq logarithmic average formula for community noise measurement. This was also used by Oyedepo (2012). The formulae were used to calculate total average logarithmic value for each location, respectively. From the table, the highest total noise level reading for the morning of the five days was recorded in Ipata $74 \mathrm{~dB}(\mathrm{~A})$, closely followed by Adeta 73.7 dB (A), Kulende 73.3 $\mathrm{dB}(\mathrm{A})$, and Geri Alimi with $73 \mathrm{~dB}(\mathrm{~A})$, while the lowest was recorded in Sefura with 68.2 $\mathrm{dB}$ (A), closely followed by Gbagba with $68.5 \mathrm{~dB}(\mathrm{~A})$ and Oja-tuntun $69 \mathrm{~dB}(\mathrm{~A})$. The highest total noise level reading for the afternoon was recorded in Post Office 77.5
dB (A), closely followed by Niger $76.4 \mathrm{~dB}$ (A), Oja-tuntun $76.4 \mathrm{~dB}$ (A), Idi-ape $76 \mathrm{~dB}$ (A) and Kulende $76 \mathrm{~dB}$ (A). The least recorded was in Oloje $71.6 \mathrm{~dB}(\mathrm{~A})$, closely followed by Sefura $72.1 \mathrm{~dB}(\mathrm{~A})$, Oju-ekun $72.3 \mathrm{~dB}(\mathrm{~A})$ and Omoda $72.6 \mathrm{~dB}(\mathrm{~A})$.

In the evening, the highest total noise level for the five days was recorded in Isaleoja $77.7 \mathrm{~dB}$ (A), closely followed by Post office $77.5 \mathrm{~dB}$ (A) and the least noise recorded was Sefura $71.2 \mathrm{~dB}$ (A), closely followed by Gbagba $71.6 \mathrm{~dB}$ (A). The location with the highest noise of day-evening was Post Office with $81.1 \mathrm{~dB}$, followed by Isale-oja $80.3 \mathrm{~dB}(\mathrm{~A})$, Ipata $79.9 \mathrm{~dB}(\mathrm{~A})$, Idiape $79.4 \mathrm{~dB}(\mathrm{~A})$ and Geri Alimi $79.4 \mathrm{~dB}(\mathrm{~A})$, while the location with the least day-evening 
noise was Sefura $75.6 \mathrm{~dB}$ (A) followed by Gbagba $76 \mathrm{~dB}(\mathrm{~A})$ and Oju-ekun $76.5 \mathrm{~dB}$ (A).

Based on NESREA guidelines, the recommended noise level for commercial and commercial/residential location is 65 decibels and 55 decibels, respectively. Hence, an area with environmental noise level that is not greater than 65 decibels during the day is mostly considered as comfortable environment free of or with little negative physical and mental effects (Ahamad et al. 2006). This corroborates the study by Shehu et al. (2019) that respondents were exposed to noise pollution ranging from $85-115.90 \mathrm{~dB}$ (A) with average value of $102 \mathrm{~dB}$ (A) which is above the standard of $85 \mathrm{~dB}(\mathrm{~A})$ given by NESREA.

From the analyses of the five (5) days, total noise levels recorded in all locations revealed that all noise levels were higher than the acceptable recommended noise level of 65 decibels for commercial and 55 decibels for commercial/residential locations by NESREA. Noise level at 70 decibels is the level which WHO considered for hearing impairment when being exposed for 24 hours (Dursun et al. 2006). The implication of this result is that none of the selected locations has acceptable notice level in relation to the NESREA and WHO recommendations which are similar to the findings of Baloye and Palamuleni (2015). The higher levels of the noise in the selected locations were attributed to vehicular movements, shopping, saw mill industries, entertainments and ceremonial activities.

The average noise level of the total 300 readings per locations, which were taken in the morning, afternoon and evening for five days measurements, revealed that participants were exposed to nothing less than $69.2 \mathrm{~dB}$ sound pressure level. Also, $78.6 \%$ of the participants are exposed to daily noise of 8 hours and above as revealed from the study. This is higher than the recommended noise level of $65 \mathrm{~dB}$ for mixed residential areas. Hearing thresholds were measured using an Interacoustics Model AD226 audiometer instrument at frequencies $500 \mathrm{KHz} 1000 \mathrm{KHz}$ $2000 \mathrm{KHz} 4000 \mathrm{KHz}$ and $8000 \mathrm{KHz}$, respectively for each study participant. The screening at each frequency was repeated twice to ensure accurate observations. Hence, adjustment of $10 \mathrm{~dB}$ of hearing frequencies at each range was deducted from audiometer reading for each participant to meet up the booth standard noise level. The hearing threshold revealed notch at $4000 \mathrm{KHz}$ for most of the participants in both ears, justified as noise induced hearing loss (WHO 1997, Biassoni et al. 2014, England and Larsen 2014).

\section{Impact of noise pollution on the health (hearing ability) of men and women}

The gender health effect of noise pollution analysis of the shift in hearing threshold revealed that none of the male participants had normal hearing as revealed in Table 4, while $0.5 \%$ females had normal hearing, $32 \%$ of the males and $58.3 \%$ of the female participants had mild hearing levels with hearing frequencies from $26-40 \mathrm{KHz}$, respectively. This is similar to the findings by Wang et al. (2021) that males had a significantly higher risk of both HFHL (OR = $4.19,95 \%$ CI 3.18 to 5.52 ) and LFHL (OR = 1.49 , 95\% CI 1.00 to 2.20 ) than females. Furthermore, $47.8 \%$ males and $25.1 \%$ females of the total participants had moderate hearing levels. 
Table 4: Gender health effect of noise pollution

\begin{tabular}{|c|c|c|c|c|c|c|}
\hline & & Shift in thre & hold cross $t$ & lation & & \\
\hline & & Shift in thresho & & & & Total \\
\hline & & $\begin{array}{l}\text { Less than } 25 \\
\text { Khz Normal } \\
\text { Hearing Level }\end{array}$ & $\begin{array}{l}26-40 \mathrm{Khz} \\
\text { Mild } \\
\text { Hearing } \\
\text { Level }\end{array}$ & $\begin{array}{l}41-55 \mathrm{Khz} \\
\text { Moderate } \\
\text { Hearing Level }\end{array}$ & $\begin{array}{l}56-70 \mathrm{Khz} \\
\text { Moderately } \\
\text { Severe Hearing } \\
\text { Level }\end{array}$ & \\
\hline Gender & Male & 0 & 67 & 100 & 42 & 209 \\
\hline & Female & 2 & 102 & 44 & 27 & 175 \\
\hline Total & & 2 & 169 & 144 & 69 & 384 \\
\hline
\end{tabular}

Source: Authors' Field Survey (2019).

At least $20.1 \%$ male participants had moderately severe hearing levels, while $15.4 \%$ female participants were in this category. The level of moderately severe hearing level is the hearing frequency between $56-70 \mathrm{KHz}$ which is a risk of gradual hearing loss. The cross-tabulation analysis (Table 4) revealed that males had high effects of noise exposure at most of the frequencies tested. Findings revealed that males are more susceptible to the effects of noise in the commercial/residential and road junctions as revealed by the study. Corroborating this is the study by Arokoyo et al. (2016) that the noise level was above $70 \mathrm{~dB}$ (A) in many junctions which is above the maximum limit given by the WHO. This may not be unconnected to the fact that they are more involved in activities that generate noise such as studio work, handling of public address system, operating generating sets, gathering for relaxation at most road junctions of the metropolis and industrial workers among others. Two-way ANOVA analysis was carried out to know whether the independent variables or their interactions were statistically significant.

From the analysis, the test between subject effects as shown in Table 5, revealed that the independent variable gender and noise level have statistically significant effects and interactions on the dependent variable "Shift in hearing threshold", this finding was corroborated by Lake (2016) whose study established that a statistically significant gender by frequency interaction was also identified, from the significant column at $\mathrm{P}=$ 0.014 , there was no statistically significant difference in shift in hearing threshold and noise level at $\mathrm{P}=0.207$ (Grinn et al. 2017), while there is also significant difference in shift in hearing threshold between males and females $(\mathrm{P}=0.032)$ at $500 \mathrm{kHz}, 1000 \mathrm{kHz}$, $2000 \mathrm{kHz}, 4000 \mathrm{kHz}$ and $8000 \mathrm{kHz}$ frequencies of the total population screened which was supported by Park et al. (2016) but was in contrast when compared with the research findings by Shuster et al. (2019) which stated that while hearing loss affects both men and women, no sex-differences in threshold shifts were detected between males and females. The results were further subjected to post hoc tests to determine the simple mean effects, which involve determining the mean differences in shift in hearing thresholds between genders at each noise levels.

The post hoc test analysis of Table 6 shows that at $500(23.7)$ and $2000 \mathrm{KHz}$ (23.9), the mean threshold level was found to be similar for both males and females. Whereas at $4000 \mathrm{KHz}(34.1)$ and $8000 \mathrm{KHz}$ (30.6), the mean threshold frequency level of hearing for males were worse than the hearing frequency levels for females (Tables 4 and 5), while hearing frequency was distinctively different and better for female at $1000 \mathrm{KHz}$ (19.1). 
Table 5: Health effects of noise pollution on gender

\begin{tabular}{llllll}
\hline Source & Type III sum of squares & Df & Mean square & F & Sig. \\
\hline Corrected model & $4.760^{\mathrm{a}}$ & 4 & 11.760 & 3.153 & 0.032 \\
Intercept & 698.760 & 1 & 698.760 & 1251.611 & 0.930 \\
$\mathrm{G}$ & 0.300 & 1 & 697 & 724 & 0.032 \\
$\mathrm{NL}$ & 1.760 & 2 & 1.760 & 3.153 & 0.017 \\
$\mathrm{G}{ }^{*} \mathrm{NL}$ & 1.502 & 2 & 752 & 1.505 & 0.014 \\
Error & 52.479 & 380 & 0.558 & & \\
Total & 753.000 & 384 & & & \\
Corrected total & 54.240 & 383 & & & \\
\hline
\end{tabular}

Dependent variable: Shift in hearing threshold, $\mathrm{R}$ Squared $=0.032$ (Adjusted $\mathrm{R}$ squared $=$ 0.022) a, Source: Authors' Field Survey (2019).

Table 6: Post hoc test analysis for the simple mean difference in shift in hearing threshold between genders

\begin{tabular}{llll}
\hline Frequency grouping & Mean difference (I-J) & Std. Error & Significance \\
\hline $500 \mathrm{Khz}$ & 23.662 & 0.36349 & 0.835 \\
$1000 \mathrm{Khz}$ & 19.149 & 0.36121 & 0.141 \\
$2000 \mathrm{Khz}$ & 23.877 & 0.17714 & 0.542 \\
$4000 \mathrm{Khz}$ & 34.118 & 0.18175 & 0.686 \\
$8000 \mathrm{Khz}$ & 30.564 & 0.38057 & 0.493 \\
\hline
\end{tabular}

Based on observed means. The error term is mean square (error) $=0.366$ at $95 \%$ confidence interval. Source: Authors' Field Survey (2019).

The results of the post hoc test as revealed in Table 7 show that the shift in hearing threshold of the noise level of 70-71 dB
(69.45) and that of the 72-73 dB (69.95) were similar to each other but both are different from noise level of above $73 \mathrm{~dB}$ (71.50).

Table 7: Post hoc test analysis for the simple mean difference in shift in hearing threshold between genders.

Multiple comparisons

Dependent Variable: Shift in threshold

Duncan multiple range test result comparing the means effect of noise pollution and gender on shift in hearing threshold.

\begin{tabular}{|l|l|l|l|l|l|l|}
\hline (I) Noise level Av & $\begin{array}{l}\text { (J) Noise level } \\
\text { Av }\end{array}$ & $\begin{array}{l}\text { Mean } \\
\text { difference } \\
(\text { I-J) }\end{array}$ & $\begin{array}{l}\text { Std. } \\
\text { Error }\end{array}$ & & Sig. & \multicolumn{2}{|l|}{$\begin{array}{l}\text { 95\% Confidence } \\
\text { interval }\end{array}$} \\
\cline { 3 - 7 } & & & & $\begin{array}{l}\text { Lower } \\
\text { bound }\end{array}$ & $\begin{array}{l}\text { Upper } \\
\text { bound }\end{array}$ \\
\hline Above 73 dB & $72-73$ & 71.50 & 0.32076 & 0.920 & 0.8894 & 0.6394 \\
\cline { 2 - 7 } & Above 73 & 69.98 & 0.32329 & 0.606 & 1.0800 & 0.4609 \\
\hline \multirow{2}{*}{$72-73 \mathrm{~dB}$} & $70-71$ & 71.50 & 0.32076 & 0.920 & 0.6394 & 0.8894 \\
\cline { 2 - 7 } & Above 73 & 69.45 & 0.15651 & 0.469 & 0.5575 & 0.1885 \\
\hline $70-71 \mathrm{~dB}$ & $70-71$ & 69.95 & 0.32329 & 0.606 & 0.4609 & 1.0800 \\
\cline { 2 - 7 } & $72-73$ & 69.45 & 0.15651 & 0.469 & 0.1885 & 0.5575 \\
\hline
\end{tabular}

Based on observed means. The error term is mean square (Error) $=0.549$.

Source: Authors' Field Survey (2019). 


\section{Conclusion}

Traffic constitutes highest source of noise pollution and males are more susceptible to the effects of noise than their female counterparts because of the nature of their jobs. A lot of people in the study area were not aware of how to control or handle noise related issues. The study however, has prepared avenues for further research. This is because findings have shown that the knowledge on the issue of noise pollution and its adverse effects on human health and the environment is yet to receive adequate attention as expected. Noise pollution threatens human health and if adequate attention/effort is not devoted to it, it will get to the stage whereby there will be decrease in human productivity. Hence, possible mitigation measures such as noise pollution regulatory policy enactment and design of noise absorbing structures are strongly recommended. Road traffic should be controlled by appropriate authority, and there is the need to develop noise maps for every big city in Nigeria as this will serve as a noise control measure. Also, awareness should be created for people about the devastating effects of noise on human health and measures on how to reduce noise exposure at individual and community levels. Furthermore, people residing or working in or near the noise risked zones such as road junctions should use ear-protection aids to reduce the effects of noise on their health.

\section{References}

Ahamad J, Abbas A and Reem S 2006 Evaluation of traffic noise pollution, Environmental Monitoring and Assessment 120: 499-525.

Ajibade LT 2002 Indigenous Systems of Land Evaluation in the Yoruba Speaking Area of Kwara State, PhD Thesis. Department of Geography, Obafemi Awolowo University (OAU), Ile-Ife, Osun State, Nigeria.

Alberola J, Flindell H and Bullmore J 2005 Variability in road traffic noise levels. European Commission, Applied Acoustics 66(10): 1180-1195.

Aremu AS, Aremu AO and Olukanni DO 2015 Assessment of Noise pollution from sawmill activities in Ilorin, Nigeria. Niger. $J$. Technol. 34(1): 72-79.

Arokoyo SB, Emenike G and Atasi LT 2016 Assessment of road junctions' levels in Yenagoa Metropolis, Nigeria using geographic information systems. Nat. Sci. 14(3): 82-96.

Awosusi AO and Akindutire IO 2014 Perceived health effects of environmental noise pollution on the inhabitants of Ado-Ekiti Metropolis. Ekiti State, Nigeria. J. Biol. Agric. Healthcare 4: 26.

Babisch W 2002 The noise/stress concept, risk assessment and research needs. Noise Health 4: 1-11.

Baloye DO and Palamuleni LG 2015 A comparative land use-based analysis of noise pollution levels in selected urban centers of Nigeria. Int. J. Environ. Res. Public Health 12(10): 12225-12246.

Basner M, Babisch W, Davis A, Brink M, Clark C, Janssen S and Stansfeld S 2014 Auditory and no-auditory effects of noise on health. Lancet 383: 1325-1332.

Biassoni EC, Serra MR, Hinalaf M, Abraham M, Paylik M, Villalobo JF, Curet C, Joekes S, Yacci MR and Righetti A 2014 Hearing and loud music exposure in a group of adolescents at the ages of 14-15 and retested at 17-18. Noise Health 16 (72): 331-341.

Clark C and Stanfeld SA 2007 The effect of transportation noise on health and cognitive development: a review of recent evidence. Int. J. Comp. Psychol. 20: 145-158.

Dursun Ozdemir C, Karaburk H and Kocak S 2006 Noise pollution and map of Konya City in Turkey. J. Int. Environ. Appl. Sci. 1(2): 63-72.

EEA 2009 Transport at a Crossroads-TERM 2008: Indicators Tracking Transport and Environment in the European Union (No. 3/2009). European Environment Agency, Copenhagen, Denmark.

England B and Larsen JB 2014 Noise levels among spectators at an intercollegiate sporting event. Am. J. Audiol. 23(1): 81-80.

Eriksson C, Nilsson, ME, Willers SM, Gidhagen L, Bellander T and Pershagen G 2012 Traffic noise and cardiovascular health in Sweden: The roadside study. Noise Health 14(59): 140-147.

Eriksson C, Bodin T and Selander J 2017 Burden of disease from road traffic and railway noise-a quantification of healthy life 
years lost in Sweden. Scand. J. Work. Environ. Health 43: 519-525.

Essando P, Armah F, Afrifa E and Pappoe A 2011 Determination of ambient noise levels and perception of residents in halls at the University of Cape Coast, Ghana. Environ. Nat. Resour. Res. 1(1): 181.

Farooqi Z, Zhabir M, Zeeshan, N Murtaza G, Hussain MM and Ghan MU 2020 Vehicular noise pollution: its environmental implications and strategic control. In: Autonomous Vehicle and Smart Traffic. IntechOpen.

Grinn SK, Wiseman KB, Baker JA and Le Prell CG 2017 Hidden hearing loss? No effect of common recreational noise exposure on cochlear nerve response amplitude in humans. Front. Neurosci. 11: 465.

Godson REA, Derek GS, Brown GE and Sridhar MKC 2009 Assessment of noise and associated health impacts at selected secondary schools in Ibadan. Niger. J. Environ. Public Health 2009, Article ID 739502.

HSE (Health and Safety Executive) 2005 Controlling Noise at Work. https://www.hse.gov.uk.

Ifabiyi IP, Ashaolu, ED and Omotosho O 2016 Hydrogeological characteristics of groundwater yield in shallow wells of the regolith aquifer: a study from Ilorin, Nigeria. Momona Ethiop. J. Sci. 8(1): 2336.

Ijaiya H 2014 The legal regime of noise pollution in Nigeria. Beijing Law Rev. 5: 16.

INEC (Independent National Electoral Commission) 2015 Kwara State Directory of Polling Units Publication of INEC. Abuja, Nigeria.

INEC 2019 National Publication of Registered Voters for the 2019 General Election. Federal Republic of Nigeria Official Gazette.

IRGC (International Risk Governance Council) 2005 Risk Governance-Towards an Integrative Approach, White Paper No.1, Renn, $\mathrm{O}$ with Annex by P Graham, Geneva: IRGC.

Kamal M, Nessi, N and Saber H 2010 Evaluation of noise levels in Cairo Governorate-Egypt. $\quad 17^{\text {th }} \quad$ International Congress on Sound and Vibration 2010, ICSV 2010. 3. 1891-1898.
Krejcie RV and Morgan DW 1970 Determining sample size for research activities. Edu. Psychol. Measure. 30: 607-610.

Lake A B 2016 The effect of noise exposure on auditory threshold, otoacoustic emissions, and electrocochleography. $\mathrm{PhD}$ thesis, East Carolina University.

Lebiedowska B 2005 Acoustic background and transport noise in urbanised areas: a note on the relative classification of the city soundscape. Trans. Res. Part D, Transp. Environ. 10(4): 341-345.

Li B, Tao S and Dawson RW 2002 Evaluation and analysis of traffic noise from the main urban roads in Beijing. Appl. Acoust. 63(10): 1137-1142.

NPC (National Population Commission) 2006 Population Census of the Federal Republic of Nigeria. Analytical Report of the National level, NPC, Abuja.

Negahdari H, Javadpour S, Moattar F and Negahdari H 2018 Risk Assessment of noise pollution by analyzing the level of sound loudness resulting from central traffic in Shiraz. Environ. Health Eng. Manage. J. 5(4):211-220.

NESREA (National Environmental Standards and Regulation Enforcement Agency) 2009 National Environmental Noise Standards and Control Regulations. Federal Republic of Nigeria Official Gazzete. 96(67):5 FGP 104/102009/1,000 (OL 60) Federal Government Printer.

NIOSH 2010 Occupationally-Induced Hearing Loss. DHHS (NIOSH) Publication No. 2010-136. Cincinnati, OH.

Nwabuogo OE and Stephen AO 2017 Assessment of Environmental Effects of Noise Pollution in Auchi, Nigeria. Appl. Sci. Rep. 18(3):100-104.

Olaniran OJ 2002 Rainfall Anomalies in Nigeria: The Contemporary Understanding. The Fifty Fifth Inaugural Lecture of the University of Ilorin.

Olanrewaju RM 2009 The climate effect of urbanization in a city of developing country: the case study of Ilorin, Kwara State, Nigeria. Ethiop. J. Environ. Studies Manage. 2 (2): 67-72.

Oloruntoba EO, Ademola RA, Sridhar MKC, Agbola S A, Omokhodion F O, Ana GRE and Alabi RT 2012 Urban environmental noise pollution and perceived health effects 
in Ibadan, Nigeria. Afr. J. Biomed. Res. 15: 77-84.

Oyedepo SO 2012 Environmental noise pollution in Ilorin Metropolis, Nigeria Nat. Environ. Pollut. Technol. Int. Q. Sci. J. 11(4): 553-567.

Park YH, Shin S-H, Byun SW, Kim JY 2016 Age- and gender-related mean hearing threshold in a highly-screened population: The Korean National Health and Nutrition Examination Survey 2010-2012. PLoS One Health 11(3): e0150783.

Pucher J, Korattyswaropam N, Mittal N and Ittyerah N 2005 Urban transport crisis in India. Transp. Policy 12(3): 185-198.

Pyko A 2018 Long-term exposure to transportation noise in relation to metabolic and cardiovascular outcomes. Thesis for Doctoral Degree (Ph.D.). Institute of Environmental Medicine Karolinska Institutet, Stockholm, Sweden.

Schomer P 2001 Assessment of Noise Annoyance. A White Paper by Schomer and Associates, Inc., (pp. 39).

Shehu WT, Sawyerr HT and Ibrahim ML 2019 Occupation noise exposure and hearing impairment among grain millers in Ita-Amo Market, Ilorin Metropolis, Kwara State, Nigeria. J. Adv. Med. Med. Res. 31(11): 110.

Shuster BZ, Depireux DA, Mong JA and Hertzano R 2019 Sex differences in hearing: Probing the role of estrogen signalling. $J$. Acoust. Soc. Am. 145: 3656-3663.

Singh N and Davar SC 2004 Noise pollution: sources, effects and control. J. Human Ecol. 16(3):181-187.
Tansatcha M, Pamanikabud P, Brown AL and Affum JK 2005 Motor-way noise modelling based on perpendicular propagation analysis of traffic noise. Appl. Acoust. 66(10):11351150.

Tunde AM 2017 Motivations for involvement in urban catfish farming and sustainable food security in Nigeria. Ann. Univ. Oradea, Geogr. Ser. 27(2): 236-245.

Wang Q, Wang X, Yang L, Han K, Huang Z and $\mathrm{Wu} \mathrm{H} 2021$ Sex differences in noiseinduced hearing loss: a cross-sectional study in China. Biol. sex Differ. 12(1): 24.

WHO (World Health Organisation) 1997 Prevention of Noise-induced Hearing Loss. Report of an informal Consultation. Geneva, retrieved from http://www.who.int/pbd/deafness/en/noise.p df

WHO 2005 Adverse Health Effects of Noise. Guideline for Community Noise, Geneva, Switzerland: WHO Report on Pollution Effects and Control 21: 28-37.

WHO 2009 Night Noise Guidelines for Europe. World Health Organization Regional Office for Europe, Copenhagen.

Zannin PHT Calixto A Diniz F and Ferreira JAC 2002 Survey of urban noise annoyance in a large Brazilian City: The importance of subjective analysis in conjunction with objective analysis. Environ. Impact Assess. Rev. 23: 245-255. 